\title{
Fisheries, food, and health in the USA: the importance of aligning fisheries and health policies
}

\author{
David Clifford Love ${ }^{1,2^{*}}$, Patricia Pinto da Silva ${ }^{3}$, Julia Olson ${ }^{3}$, Jillian Parry Fry ${ }^{1,2,4}$ and Patricia Mary Clay ${ }^{3}$
}

\begin{abstract}
Background: Food availability, access, and utilization are the three pillars of food security and need to be aligned in order to support a healthy population. United States (US) fisheries policy plays an important role in seafood availability. US health policy impacts access and utilization of seafood in various ways; however, health policies are often disconnected from fisheries policy. Aligning fisheries and health policies is imperative to improve food security. We address two questions with our work: (1) how would US federal fisheries policy be different if our fisheries were managed with beneficial health outcomes for Americans as clear objectives; and (2) how would US health policy be different if one of its goals was to support sustainable domestic fisheries and aquaculture?
\end{abstract}

Results: We report how fisheries policies and health policies are additive, synergistic, or antagonistic with regard to seafood, and provide illustrative examples of collaboration between health and fisheries communities at different levels of the food system (federal and state policies, corporate partnerships, and civil society). We also develop a list of topics for future research, and opportunities to align and integrate fisheries and health policies.

Conclusions: Managing fisheries to promote optimal nutrition and efficient food production likely requires a different approach to fisheries management-new outcomes will need to be monitored, new approaches found, and fisheries, aquaculture, and health policies better integrated. Health policies rarely consider the source of fish, their connections with US fisheries systems, and global distribution of seafood. Change can begin where the most promising opportunities exist, such as institutional food procurement, Farm to School programs, social marketing campaigns, and private sector start-ups. Continued development in fisheries and health policies, however, will need to occur at multiple levels of federal policy, and across the different domains and dimensions of the food system (e.g., social, political, biophysical, economic).

Keywords: Aquaculture, Fisheries, Food, Health, NOAA, Policy, USDA

\section{Background}

Fish and other types of aquatic animal and plant species are an integral part of human economies, cultures, and health. Here, we refer to those species using the term "seafood" to include freshwater and marine species, principally those caught in commercial fisheries or grown

\footnotetext{
*Correspondence: dlove8@jhu.edu

${ }^{2}$ Department of Environmental Health and Engineering, Bloomberg

School of Public Health, Johns Hopkins University, 615 N. Wolfe Street, Baltimore, MD, USA

Full list of author information is available at the end of the article
}

through aquaculture. ${ }^{1}$ Seafood supports the livelihoods of $10-12 \%$ of the world population [1]. Seafood is considered part of a healthy diet, providing nearly 3 billion people with $20 \%$ of their dietary protein needs and

\footnotetext{
$\overline{{ }^{1} \text { We have limited our focus to federal fisheries because we are connecting }}$ federal fisheries policies to federal food policies. Furthermore, we concentrate on commercial fisheries because much recreational and subsistence fishing is regulated at the state level. To the extent federal recreational fishing regulations exist, comparable recreational catch data are not yet available for all states. Meanwhile, subsistence fishing that is governed by federal regulations is often governed under special community-oriented programs that are not easily comparable with standard fisheries governance structures.
} 
micronutrients such as iodine, potassium, selenium, B vitamins, and vitamin $\mathrm{D}[1,2]$. The omega- 3 polyunsaturated fatty acids (PUFAs) in seafood support childhood development and reduce risks from heart disease $[3,4]$. Underscoring the importance of seafood, the United States (US) and other national dietary recommendations call for increasing seafood consumption, particularly fish high in omega-3 PUFAs and low in mercury $[5,6]$. Yet at the same time, fisheries experts and health experts are raising questions about whether national dietary recommendations are in fact achievable, equitable, and sustainable, given what some see as a diminished seafood supply from the world's oceans and general movement of seafood products from low- and middle-income countries to high-income countries [1,7-11]. The underexplored intersection of these policy spheres, with different concerns and goals, has significant implications for future scenarios in both health and sustainability.

For millennia, wild capture fisheries were often viewed as inexhaustible resources. Today, scientists believe that the global fishing fleet reached its "peak catch" in 1996 at 130 million metric tons (MMT), with subsequent harvests declining by about 1.2 MMT each year [12]. Others have challenged the idea that global fisheries collapse is as imminent as predicted, and authors of both competing views found a patchwork of recovery and decline in different fisheries and regions around the world [13]. A combination of factors is driving many (but not all) fish stocks to decline, including: increased human demand due to population growth and rising incomes; overfishing; use of better technology to catch seafood by large fishing fleets; illegal, unregulated, unreported (IUU) fishing; poor management decisions in some fisheries; and the impacts of climate change (e.g., increasing ocean acidification and ocean temperatures) and biodiversity loss [13-17]. Humans have entered a new epoch, the Anthropocene, where human influence permeates the planet and decreasing wild harvests affect global food security $[12,18]$.

Aquaculture, or aquatic animal and plant farming, has helped fill the gap between demand for seafood and declining wild fisheries [19]. Aquaculture has buoyed the global edible seafood supply and now contributes equal amounts to wild capture, in terms of seafood used for human consumption [20]. However, despite the different trajectories for aquaculture and wild capture fisheries, fed aquaculture (i.e., species requiring feed inputs) cannot be considered independently from wild capture fisheries or terrestrial crop production. Carnivorous farmed species like Atlantic salmon, trout, and marine shrimp still rely on feeds containing ingredients from wild-caught forage fish, such as anchovies, herring, and sardines, which tightly couples fisheries and aquaculture and introduces natural resource trade-offs [21,22] that may impact food system resilience. The use of fishmeal and oil has greatly decreased in carnivorous farmed species, and the use of alternative feeds from terrestrial sources (e.g., soybean meal and oil, corn, other vegetable oils, animal byproducts) has increased in herbivorous, omnivorous, and carnivorous species. This links aquaculture with terrestrial agricultural systems and creates trade-offs that potentially impact the resilience of global food systems [23, 24]. Given these multiple connections, national policies related to fisheries and agriculture will have ripple effects on aquaculture production costs, and the human food supply and nutrition [23].

A recognition of the complex and interrelated set of challenges in the commercial seafood sector provides the contextual foundation for this paper. We follow these challenges as a means of exploring how current fisheries and health policies are additive, synergistic, or antagonistic with regard to seafood. Admittedly, we are necessarily juxtaposing different institutions' ideas and practices about best uses for seafood; as we will discuss later, ideas and practices in one US-based institution can be inconsistent with another, or even internally inconsistent, due in part to differing priorities reflecting divergent values and social beliefs. Throughout this paper, we take the perspective that fish (including finfish and shellfish) is food and, more specifically, that seafood is a key ingredient in a food system [25]. Our aim is to highlight the policy intersections of fisheries and health and raise important questions while exploring this juncture.

In this study, we ask two questions: (1) how would US federal fisheries policy be different if our fisheries were also managed with health outcomes for Americans as clear management objectives; and (2) how would US health policy be different if one of its goals was to support sustainable domestic fisheries and aquaculture? As we begin to explore these questions, looking at past and current activities within US public health and fisheries management, we provide illustrative examples of collaboration and disconnects between health and fisheries management communities at different levels of the food system (federal and state policies, corporate partnerships, and civil society). Finally, we discuss opportunities to align fisheries and health policy and suggest priority areas for further research.

\section{Methods}

The study began with an exploratory phase consisting of six months of regular dialogue among an interdisciplinary research team, composed of two public health experts (Love and Fry) and three fisheries experts (Pinto da Silva, Olson, and Clay). This dialogue gave study team members an opportunity to better understand each 
others' disciplines and identify gaps in knowledge across the disciplines. Following the exploratory phase, the study team formulated two overarching questions related to the interactions between fisheries and public health. To answer the questions, the research team identified relevant background information about health policy and fisheries policy through federal agency Web sites, communicating with experts/stakeholders, reading literature available on PubMed and Google Scholar, and sharing our expert knowledge. This information was compiled in the "Background," "Health policy," and "Fisheries policy" sections.

In the health policy section, data in Table 1 on US nutrition assistance programs were compiled using the US Department of Agriculture Web site and in consultation with Janice Fitzgerald, Household Programs Operations Branch Chief at the US Department of Agriculture, Food, and Nutrition Service. To identify American seafood consumption trends for Table 2, a search was performed in PubMed for the literature on seafood consumption using the NHANES dataset from the 1980s to present, and data from five sources were extracted and compiled. In "Fisheries policy" section, the annual commercial catch of forage fish in the USA was found in the National Marine Fisheries Service (NMFS) "Commercial Fisheries Statistics" database (in metric tons and value) and we report averages of yearly data from 2003 to 2013. Data on US edible and industrial seafood supply were procured from the 2013 edition of the NMFS annual report "Fisheries of the United States, 2013."

We then developed five case studies to provide readers with tangible examples of synergy between fisheries and public health. These case studies were carefully selected to represent different levels of the food system and different entry points into the supply chain. To write the case studies, the team conducted background research and informal interviews with an environmental advocate, a fishmonger, a seafood wholesaler, a university food service provider, a canned fish business owner, and a fishing industry representative. Notes from these interviews were compiled and drafted into case reports. We followed up with some interviewees to check facts and ask additional questions.

Finally, the study team jointly developed a set of recommendations and conclusions based on the research conducted. The team shared these recommendations with external reviewers, a fisheries economist and an agriculture/health policy expert, for comments and revisions.

\section{Results and discussion \\ Health policy \\ Nutritional benefits and seafood safety}

To understand health policy related to seafood, it is useful to understand its scientific underpinnings in two of the most important disciplines: nutrition and food safety. Among the most significant health benefits of seafood are

Table 1 US nutrition assistance programs that support seafood purchasing, 2013

\begin{tabular}{|c|c|c|c|c|c|}
\hline Federal program & Approved seafood & $\begin{array}{l}\text { People } \\
\text { participating } \\
\text { annually (millions) }\end{array}$ & $\begin{array}{l}\text { Total cost } \\
\text { (million US } \\
\text { dollars) }\end{array}$ & $\begin{array}{l}\text { Seafood } \\
\text { cost } \\
\text { (million) }\end{array}$ & $\begin{array}{l}\text { Seafood quantity } \\
\text { purchased } \\
\text { (million pounds) }\end{array}$ \\
\hline Supplemental Nutrition Assistance Program & Any seafood ${ }^{\mathrm{a}}$ & 47.4 & 79,936 & $\mathrm{n} / \mathrm{a}$ & $\mathrm{n} / \mathrm{a}$ \\
\hline \multicolumn{6}{|l|}{ Child Nutrition Programs } \\
\hline National School Lunch Program & Numerous products ${ }^{b}$ & 30.6 & 12,220 & 7.5 & 1.6 \\
\hline School Breakfast Program & $\mathrm{n} / \mathrm{a}$ & 13.2 & 3514 & & \\
\hline Summer Food Service Program & $n / a$ & 2.4 (daily) & 428 & & \\
\hline Child/Adult Care Program & $n / a$ & 3.6 (daily) & 2994 & & \\
\hline Women, Infants, and Children Program & $\begin{array}{l}\text { Canned chunk light tuna, } \\
\text { pink salmon, sardines }\end{array}$ & 8.7 & 6488 & $\mathrm{n} / \mathrm{a}$ & $\mathrm{n} / \mathrm{a}$ \\
\hline \multirow[t]{3}{*}{ The Emergency Food Assistance Program } & & $\mathrm{n} / \mathrm{a}$ & 693 & 13.7 & 3.8 \\
\hline & Canned pink salmon & & & 3.8 & 1.7 \\
\hline & Unbreaded catfish fillets & & & 9.9 & 2.1 \\
\hline Commodity Supplemental Food Program & Canned pink salmon & 0.58 & 203 & 3.0 & 1.3 \\
\hline Food Distribution on Indian Reservations Program & Canned pink salmon & 0.09 & 119 & 0.43 & 0.2 \\
\hline National Services Incentive Program (elderly feeding) & Catfish, frozen fillet strips & 0.076 & 100 & 0.19 & 0.04 \\
\hline Total & & 100.6 & 106,695 & 24.8 & 6.9 \\
\hline
\end{tabular}

Data source: [102]

a Except hot food or food that can be eaten in the store

b Fresh/frozen clams, crabs, crawfish, fish fillets and steaks, fish portions, fish sticks, mackerel, oysters, scallops, squid, canned mackerel salmon, chunk light tuna, sardines, shrimp 
Table 2 Consumption of seafood by Americans from 1988 to 2010, NHANES

\begin{tabular}{|c|c|c|c|c|c|}
\hline \multirow[t]{2}{*}{ Study } & \multicolumn{2}{|c|}{ Per capita mean intake (g/week) } & \multicolumn{2}{|c|}{$\begin{array}{l}\text { Among seafood consumers (past } 30 \text { days) mean } \\
\text { intake (g/week) }\end{array}$} & \multirow[t]{2}{*}{ Year } \\
\hline & Men (+19 years) & Women (+19 years) & Men (+19 years) & Women (+19 years) & \\
\hline $\mathrm{NCl}[104]$ & 138.9 & 99.2 & - & - & $2007-2010$ \\
\hline Jahns et al. [62] & - & - & 179.2 & 138.6 & 2005-2010 \\
\hline Papanikolaou et al. [103] & 140.1 & 101.2 & - & - & 2003-2008 \\
\hline Tran et al. [105] & 128.7 & 86.3 & 186 & 127.8 & 1999-2006 \\
\hline Wang et al. [106] & 115.5 & 84.7 & - & - & 1999-2004 \\
\hline Wang et al. [106] & 141.4 & 100.8 & - & - & 1988-1994 \\
\hline
\end{tabular}

Data sources: $[62,103-106]$

those derived from the omega-3 polyunsaturated fatty acids (PUFAs) present in many types of seafood. Fish high in omega-3 fatty acids include herring, mackerel, sardines, and salmon. In infants, there is strong evidence of gains in childhood development when pregnant and nursing mothers consume seafood, and limited evidence for a protective effect for asthma and eczema [3]. For adults, some of the best evidence that seafood consumption provides health benefits is the prevention of cardiac deaths in individuals with preexisting coronary heart disease [4]. There is limited evidence that seafood consumption later in life improves bone health and is protective against dementia; however, more studies are needed [2]. Seafood is a lean protein and can serve as a replacement for meat high in saturated fat. Importantly, fish oil supplements are not always associated with the same health benefits as eating a meal of a whole seafood product [3, 26]. In addition to nutrition, there are psychological, psychosocial, cultural, health, and food security benefits of consuming locally produced seafood [27-29].

Some of the health benefits of seafood are offset by food safety risks, such as naturally occurring biotoxins, metals, microbiological agents, other pollutants, and allergens present in some seafood. The most well-known contaminant associated with seafood is methylmercury $(\mathrm{MeHg})$, a neurotoxin that enters the ocean primarily by deposition from burning fossil fuels and accumulates in the marine food web. Individuals eating large amounts of long-lived marine fish (e.g., shark, swordfish, king mackerel) and bottom-feeding fish (e.g., tilefish, catfish) are most at risk of negative health effects, particularly fetuses and infants exposed via their mother's intake of contaminated seafood [3]. Persistent organic pollutants (POPs), metals, and pesticides can be present in both saltwater and freshwater fish near urban centers, and people who practice subsistence fishing can be exposed to unsafe levels of pollutants $[30,31]$. Biotoxins can include toxins produced by algae and incorporated into shellfish (i.e., paralytic shellfish poisoning) or fish (i.e., ciguatera), and naturally occurring marine bacteria (i.e.,
Vibrio spp.) that produce toxins in shellfish. Foodborne diseases from seafood are not uncommon, occurring most frequently through consumption of filter-feeding shellfish, raw fish products, or improperly handled or stored processed or imported seafood [32,33].

On balance, the benefits of seafood outweigh the risks [34], which undergirds many health policies related to seafood. In fact, many policies are intended to increase seafood consumption to meet national dietary guidelines.

\section{Policies related to seafood and health}

There are many US health policies regarding seafood, primarily related to access and use of seafood but also food safety issues related to production and processing. To start this section, we familiarize readers with the federal agencies involved in seafood as it relates to human health, and describe each type of policy-be it dietary advice, labeling, or nutrition assistance. Most of these policies are inclusive of fisheries and aquaculture, and we note where differences exist. Additional detail, specifically on fisheries policy that affects seafood availability, is provided in the "Fisheries policy" section.

Overview of federal agencies involved in seafood as a food source Federal oversight of fisheries and aquaculture production is split among three agencies. The National Marine Fisheries Service (NMFS), which is a line office within the National Oceanic and Atmospheric Administration (NOAA), has regulatory purview over marine fisheries and aquaculture in federal waters and the Great Lakes $[35,36]$. Freshwater and inland aquaculture is overseen by the US Department of Agriculture (USDA) [37]. Freshwater fishing outside of the Great Lakes is overseen by the Fish and Wildlife Service; however, their focus is not on food but rather on conservation.

Specific to aquaculture, the Food and Drug Administration (FDA) regulates veterinary drug use in farmed aquatic animals [38]. Aquaculture operations receive assistance from the USDA Animal and Plant Health Inspection Service (APHIS) for disease control, and live 
organisms originating from fish hatcheries are inspected by APHIS for diseases before sale across state or national borders [39]. The USDA is also in the process of developing organic standards and a USDA Organic label for aquaculture producers, which would limit the use of synthetic chemicals, certain feed ingredients, and some production methods; however, the draft regulation has not been released as of time of publication for this article [40]. Organic standards for aquaculture have come much later than organic standards for meat, dairy, fruits, and vegetables, in part because of the complexity and variety within aquaculture production methods and the relatively small size of the aquaculture industry in the US.

More generally, for all fisheries and aquaculture products, the FDA-along with support from NOAA, and USDA (for catfish)-inspects a small proportion of domestic and imported seafood and seafood processing plants [41]. NOAA will implement a new Seafood Import Monitoring Program focusing on traceability for $13 \mathrm{com}-$ mercial species beginning in 2018 [42]. The USDA specifies grades and standards for various processed seafood products (such as canned or breaded processing standards) [43]. In some cases, physical or chemical inspection occurs, and in other cases, inspection of paperwork such as trade documents, permits, and hazard analysis and critical control points (HACCP) plans are reviewed by one of these agencies $[44,45]$. Because shellfish carry a higher risk for causing disease, the FDA, in collaboration with states and the National Shellfish Sanitation Program, has special regulations concerning where shellfish can be grown or harvested in the US, and specific permits and regulations for shellfish processing and interstate trade [46]. Finally, at the end of the supply chain, state and local health departments inspect food preparation, restaurant, and retail locations to make sure they are meeting regulations for safe food handling. The Centers for Disease Control (CDC) also plays a role in food safety by assisting with outbreak investigations for foodborne disease [47].

Consumption-focused policies The Departments of Health and Human Services (HHS) and Agriculture (USDA) produce the US Dietary Guidelines every five years with dietary advice related to foods including seafood $[5,6]$. The Dietary Guidelines are developed based on input from an advisory committee that reviews the current health and nutrition literature and makes recommendations for dietary patterns [48]. The Dietary Guidelines indicate that seafood intake is below recommended levels for all age groups and should be increased. In 2015, the Dietary Guidelines Advisory Committee made recommendations about sustainability, which mainly focused on reducing meat consumption but also included some discussion of fisheries and aquaculture. Sustainabil- ity language and recommendations were not included in the final report, despite broad support from the US public [49]. The Dietary Guidelines have an impact on Americans' diets via nutrition education, food purchasing done using federal funds, and nutrition assistance programs (described below).

Product labeling is an example of a consumer-facing policy. The only government-required form of product labeling for seafood (outside of nutrition and ingredient labeling) is country of origin labeling (COOL). COOL labels report whether the product is wild-caught or farmraised and its country of origin. COOL is required for all minimally processed seafood sold in retail locations, and some consumers infer quality attributes from these labels [50]. Third-party labels, such as eco-labels, complement or fill gaps left by federal labeling laws. Food labels are important because they inform consumers about products in ways that are more direct and tangible than other approaches, such as methylmercury warnings, which are not present on seafood products.

Beginning in the early 2000s, the FDA, Environmental Protection Agency (EPA), and states began working together to advise consumers about methylmercury (MeHg) in both commercial and self-caught seafood. To help recreational anglers, the EPA worked with all 50 states to develop recreational seafood consumption advisories for the general public and women of childbearing age to reduce human exposure to $\mathrm{MeHg}$ and certain pesticides [51, 52]. The FDA and EPA also produced seafood $\mathrm{MeHg}$ advisories for retail seafood that target women of childbearing age and young children to reduce $\mathrm{MeHg}$ exposures [53]. Unfortunately, the original $\mathrm{MeHg}$ advisories had the unintended consequence of decreasing maternal seafood consumption, thereby reducing the potential benefits for these populations of eating seafood [54]. A more recent study indicates that the $\mathrm{MeHg}$ advisories' message may now be better received, as women of childbearing age are eating seafood but switching to products with lower levels of mercury [55]. The FDA and EPA are in the process of revising seafood advisories for $\mathrm{MeHg}$ in light of the expert consensus that the benefits of seafood consumption outweigh the risks $[34,56]$.

Nutrition assistance programs The USDA Food and Nutrition Service administers 15 nutrition assistance and nutrition education programs. Table 1 presents the amount and cost of seafood purchased under nutrition assistance programs by individuals (i.e., cash purchases) and by the USDA (i.e., entitlement commodity purchases). The largest program is the Supplemental Nutrition Assistance Program (SNAP, commonly known as food stamps), which in 2014 supported 46 million Americans with low incomes [57]. Individuals can spend SNAP funds to pur- 
chase any type of fresh, frozen, or processed seafood, as long as it is not a hot or prepared food that can be eaten in the store. The Nutrition Program for Women, Infants, and Children (WIC) distributes funds to eight million pregnant, low-income women and their children. WIC participants can use electronic benefit transfer (EBT) cards (similar to debit cards) to purchase canned light tuna, pink salmon, and sardines, among other food items [58].

There are also several entitlement programs in which state agencies select what types of commodity foods they want from a list of allowable products that the USDA then purchases and distributes to the states. Examples of these entitlement programs are the Emergency Food Assistance Program, which distributed over 600 million pounds of products to food banks in 2015 [59], the Food Distribution Program on Indian Reserves, which supports 276 tribes [60], and the Commodity Supplemental Food Program, which supports approximately 500,000 low-income elderly Americans annually. Rules require that the USDA purchase only domestically produced and processed foods under these entitlement programs. The only seafood product purchased by these entitlement programs currently is canned pink salmon from Alaska, with $\$ 7.2$ million (3.2 million pounds) purchased in 2013 (Table 1). Canned tuna will be approved for purchase beginning in 2016. While catfish is an allowable item, it is not typically selected by states due to its expense; instead, items like catfish tend to be purchased using the USDA bonus program, which is used to correct oversupply in the market and does not count against state entitlement spending. In 2013, the USDA purchased \$17.6 million (3.7 million pounds) of catfish (Table 1).

The Child Nutrition Program (CNP) is a hybrid program that provides both cash reimbursements for students to purchase school food and entitlement funds for schools to purchase that food. The National School Lunch Program (NSLP) is one example within the CNP; it provides five billion free and reduced-price lunches to 30.5 million school-age children through the age of 18 [61]. The list of allowable seafood products purchased through the NSLP is larger than any other nutrition assistance program (Table 1), and while schools are asked to purchase domestic food with their funds, they may choose imported products that are cheaper or more widely available. Cost is a major barrier for seafood purchasing by nutrition assistance programs, which may cause commodity purchasing programs and participants of SNAP or WIC to purchase more economical animal and plant proteins. It would be useful to identify the barriers, in addition to cost, preventing nutrition assistance programs from incorporating more domestic seafood into food banks and feeding programs. In addition, given the low consumption of seafood among women and low income Americans, consideration should be given to what role the federal government can play in encouraging seafood consumption by SNAP and WIC participants [62].

\section{Consumption trends in the USA}

Americans make food choices based on a variety of reasons. Seafood purchasing is primarily driven by consumer taste preference, cost, income, gender, age, and for some an interest in meeting national dietary recommendations $[63,64]$. American seafood consumption is as diverse as our population; however, in aggregate, the most commonly eaten seafood products are whitefish (pangasius, domestic catfish, cod, pollock, tilapia), shrimp, farmed salmon, and canned tuna. The US imports $88 \%$ of the seafood it consumes, which is equally split among wildcaught and farmed sources [65]. Most popular seafood products (with the exception of tuna, tilapia, and pollock) have farmed and wild-caught versions available in stores. Yet among the top seafood products, only salmon is high in omega-3 PUFAs, the nutritional element that drives seafood consumption guidelines. Forage fish such as anchovies, herring, and sardines are high in omega-3 PUFAs, low in contaminants like mercury, and low on the food chain; however, these products rarely appear on nutrition assistance program lists and have decreased in popularity among American consumers over the last 50 years.

Indeed, the sheer number of nutrition and health policies described above appears to encourage access to seafood that is safe, affordable, low in mercury, and shelfstable for key groups such as pregnant and breastfeeding women, children, the elderly, and individuals with low incomes. Nonetheless, from 1988 to 2010, Americans have consistently eaten much less seafood than government-recommended levels of 2-3 meals per week (227 g per week, or 8-12 oz per week) (Table 2) [5]. One study found that while four out of five Americans eat seafood on a monthly basis, most people (80-90\%) were not meeting dietary guidelines [62]. A very low proportion of Americans meet dietary recommendations in other areas, too, such as fruit and vegetable intake [66]. Women, young people (19-30 years old), and individuals with lower levels of income and education all consume less seafood than the average American [62]. These findings highlight potential inequalities in access to seafood (and/or related factors such as preferences and familiarity) among certain groups, which could contribute to health disparities.

Moreover, federal health policy does not mention the goal to support sustainable domestic fisheries and aquaculture, or include language that indicates how food systems are linked to healthy fisheries. In this sense, fisheries 
and health policies are intrinsically linked while being effectively "siloed." Below, we explore US marine fisheries policies to understand how US wild seafood resources are currently managed, and consider what changes to federal fisheries policies/management might lead to optimal food production, human nutrition, and health outcomes for Americans.

\section{Fisheries policy \\ Fisheries policy and management}

Early efforts to develop US fisheries policy began over a century ago. In 1871, Congress passed the first legislation recognizing a Federal role in conservation of natural resources: the Joint Resolution for the Protection and Preservation of the Food Fishes of the Coast of the United States [Act of February 9, 1871, Sess. III, Res. 22, 16 Stat. 593-94 (1871)]. The resolution recognized that "the most valuable food fishes of the coast and the lakes of the United States are rapidly diminishing in number, to the public injury, and so as materially to affect the interests of trade and commerce." The US Fish Commission was created to protect, preserve, and study these "food fishes." After many decades of organizational changes and realignments, duties were divided between the U.S. Fish and Wildlife Service (FWS), which governs freshwater species, and the National Marine Fisheries Service (NMFS), which governs saltwater species. In 1970, NOAA was established and "directed to improve our understanding of the nation's living marine resources, the environment in which they are found, and the interaction between the two," and NMFS (thereafter also known as NOAA Fisheries) was placed within NOAA [67].

The primary law governing marine fisheries management in federal waters is the Magnuson-Stevens Fishery Conservation and Management Act (MSA; 16 U.S.C. $\beta$ 1801 et seq.). While the MSA refers to the importance of fish as food in its definition of optimum yield (OY), ${ }^{2}$ the first of ten National Standards included in the document, fisheries regulations generally focus on rebuilding overfished stocks and ensuring that overfishing is not occurring through controls on inputs (gear restrictions/area closures) and/or outputs (limits on catch/landings) [25], but do not consider what happens to fish after it is landed or how regulatory actions might impact nutrition or food systems [68]. The US Fish and Wildlife Service regulates

\footnotetext{
${ }^{2}$ The amount of fish which will provide the greatest overall benefit to the nation, particularly with respect to food production and recreational opportunities, and taking into account the protection of marine ecosystems; is prescribed as such on the basis of the maximum sustainable yield from the fishery, as reduced by any relevant economic, social, or ecological factor; and in the case of an overfished fishery, provides for rebuilding to a level consistent with producing the maximum sustainable yield in such fishery [16 United States Code (USC) \$1802(33)].
}

freshwater fishing outside of the Great Lakes and operates fish hatcheries, fishery resource offices, and ecological services field stations [69], where the primary concern is conservation of resources and not fish as food. All federal agencies must comply with the National Environmental Policy Act (NEPA), which requires agencies to assess the environmental impacts of and alternatives to proposed actions. These assessments are conducted and shared with stakeholders and the public as Environmental Assessments (EA) or, when it is determined that a Federal action will have a significant effect on the human environment, Environmental Impact Statements (EIS). For example, EPA reviewed a large gold mine planned upstream of Bristol Bay, Alaska, and found reason for concern due to potential impacts to fisheries and the livelihood or cultural identity of fishermen. Human health could be impacted by stress from loss of income or identity; however, health issues related to how the fish are marketed after landing was not considered. In this case, the EPA conducted an EA and determined that a more detailed EIS was not required.

Fisheries policy extends to aquaculture as well, especially regarding use of wild-caught forage fish as aquaculture feed (discussed below); however, our discussion of federal aquaculture-specific policy (i.e., developed by the NOAA Office of Aquaculture or in the NMFS Aquaculture Strategic Plan) is limited in this document. NMFS directs attention to aquaculture in federal waters, where it is primarily concerned with "developing and implementing policies that enable marine aquaculture and works to ensure that aquaculture complies with existing federal laws and regulations that NOAA enforces under its marine stewardship mission" [70]. The USDA gathers data on economics and animal health of US aquaculture products, conducts a census of aquaculture operations every five years [71], and tracks US imports/exports of aquaculture products [72]. It is important to note that US government agencies are working to expand the domestic aquaculture industry, which currently contributes less than one percent of global aquaculture production [20, $73,74]$. Therefore, an opportunity exists to incorporate sustainability and health outcomes, as well as alternative supply chains, as the industry grows. In addition, integration with food systems, public health, and alternative supply chains may also serve to expand the number of stakeholder groups supporting aquaculture development in the US.

\section{Outcomes and markets}

Seafood is the most valuable traded food commodity in the global marketplace, more valuable than coffee, tea, or spices [1]. The US is a major player in global seafood trade, routinely buying and selling to/from over 
Table 3 Annual catch of forage fish in the US, mean of 2003-2013

\begin{tabular}{lrr}
\hline Forage fish species (region) & Metric tons & Value (USD) \\
\hline Anchovy (Northern) & 6796 & 883,554 \\
Mackerel (Scomber) & 4 & 4750 \\
Menhaden (Atlantic) (Brevoortia) & 659,579 & $93,930,294$ \\
Sardine (Pacific) & 80,682 & $12,286,746$ \\
Sardine (Spanish) & 591 & 228,673 \\
Herrings (Atlantic) & 72,694 & $32,398,361$ \\
Herring (Atlantic Thread) & 645 & 236,890 \\
Herring (Blueback) & 9 & 10,550 \\
Herring (Lake or Cisco) & 397 & 554,303 \\
Herring (Pacific) & 38,761 & $17,262,876$ \\
Herrings & 487 & 217,018 \\
Total forage fish & 860,645 & $158,014,015$ \\
Total US landings & $4,174,308$ & $4,399,172,575$ \\
\hline
\end{tabular}

Data source: [107]

100 countries in multiple regions of the world [75]. The major trading partners for the US are Asia and Canada [76]. This trade includes two types of products that are important to differentiate: edible products and industrial products. Edible products are what we commonly think of as the seafood that is sold in grocery stores and restaurants. Industrial fisheries products, made primarily from forage fish and fish scraps, are used as animal feed, fish feed, or fertilizer. Forage fish are small oily fish that live in schools within the water column along coasts, oceans, and lakes and are caught with large nets. In the US, over 800,000 metric tons of forage fish are caught each year, which is a fifth of US landings by weight, but just $4 \%$ by value (Table 3). Forage fish caught in the US are often turned into fishmeal and fish oil. It is difficult to convert quantities of forage fish into amounts of fishmeal and oil produced because rendering removes water weight, but NMFS reports that the US produces over 200,000 metric tons of fish meal and 70,000 metric tons of fish oil each year [1].

Once aquatic animals are removed from a body of water, they enter seafood supply chains consisting of hundreds of processors, wholesalers, distributors, and retailers that employ 1.3 million full- and part-time workers in the US [77]. Edible and industrial fisheries products are both traded, but in different ways. For example, the US imports more edible products than it exports (i.e., a negative trade balance), while the opposite occurs with industrial products - the US exports three times more industrial products than it imports (Table 4). Overall, these trading patterns have led to a food system where nine-tenths of the US edible seafood supply is imported, sometimes as US fish that has been processed abroad, and a feed system where large amounts of forage fish are extracted from US territorial waters and exported. As we will explore later in this paper, these complex interactions between supply and demand in the use of natural resources have important outcomes for human health, as well as implications for society, the economy, and ocean ecosystems.

The Atlantic herring fishery, formerly a food fishery and now a bait fishery for the New England lobster fishery, illustrates the evolution of social and economic outcomes influenced by fisheries policy. Small herring used to be canned in Maine in the nineteenth and twentieth centuries, peaking at 400 canneries that employed thousands. The last cannery in Maine closed in 2010 [78]. Changing markets and consumer preferences played some role, for example, in the dietary replacement of canned herring and sardines with canned tuna, but how Atlantic herring is caught also determines what it is used for. Fishing methods have changed since herring was used as a human food and changes in fishing methods and technology have accompanied changes in the management and use of herring. Early methods (traps called weirs and relatively small nets called seines) caught herring without damaging the fish, which was ideal for using herring as human food. Over time, regional fisheries management council regulations have allowed large trawlers and pair trawlers (trawlers working together with a net between them), to become the dominant gear types; these vessels pump large catches out of nets into onboard refrigerated seawater tanks. Fish caught this way are not marketable as human food, as they are often damaged during the process of extraction. Concurrent with these technological shifts, Atlantic herring shifted from being a food fish to a baitfish, used almost exclusively as bait for today's American lobster fishery (Pinto da Silva, Olson and Benjaman, in review). While herring was once a low-cost source of high quality protein and other nutrients, the fishery it now supports, lobster, is a high-cost (i.e., less affordable) food source. While these changes from food to bait have been exacerbated by a confluence of economic, social, technological, and cultural shifts, regulatory measures have likely contributed to this situation as well by not considering the impacts of regulatory changes on the regional and national food system.

Examining management and the use of herring and other forage fish raises the following questions: Should forage fish be managed in a way that recognizes the benefit of leaving a certain amount in the ocean to provide food for other fish higher on the food chain? Should people eat these fish instead of using it for industrial purposes, including as aquaculture feed or bait, where there is a conversion loss of protein and biomass? Herring, as well as menhaden and other forage fish, expose some of the trade-offs that are inherent in fisheries management, 
Table 4 US edible and industrial seafood supply in 2013 (million metric tons)

\begin{tabular}{llllll}
\hline Fisheries and aquaculture product & Domestic landings & Domestic aquaculture & Imports & Exports & Total supply \\
\hline Edible products & 3.7 & 0.25 & 4.8 & 3.2 & 5.5 \\
Industrial products & 0.83 & $\mathrm{n} / \mathrm{a}$ & 0.27 & 0.84 & 0.26 \\
Total & 4.5 & 0.25 & 5.0 & 4.0 & 5.7 \\
\hline
\end{tabular}

Data source: [65]

trade-offs that will only be increasingly highlighted as regulatory agencies begin to grapple with ecosystembased approaches to management. The important point in this context, however, is that how we choose to manage our fisheries will also influence the food supply in the US and beyond, making fisheries policy part of US food policy and requiring more explicit recognition of the intersection of, and especially the trade-offs between, fish, food, and health policy. As the following examples help demonstrate, expanding the universe of those involved with fisheries management can shift the objectives of concern and change the questions stakeholders are asking.

\section{Synergy between fisheries and health policy, illustrative examples}

Here, we present four illustrative examples of policies, initiatives, and business models where fisheries and health policies are purposefully connected. Each example targets a different level (federal and state government, civil society, economy) as a way to acknowledge that hybrid, multi-level interventions are needed to solve complex problems. The examples we selected are: anchovy consumption in Peru; an Alaskan government program to purchase local seafood for public school lunches; a public-private partnership between a New England university, seafood distributor, and nonprofit working to support local fishers; and a California-based canned seafood business.

\section{Social marketing: Peruvian anchovies, changing culture takes time}

Along the West Coast of South America in the Pacific Ocean lies the Humboldt Current, where a rich upwelling of nutrients supports an abundance of marine life [79]. As a result, Peru has some of the best fishing grounds for small pelagic fish, including anchovies and sardines. At the peak of anchovy fishing in 1970, 12 million metric tons of anchoveta, a type of anchovy, were harvested off the coast of Peru, constituting an astounding $20 \%$ of all global fish harvests [80]. Peruvian anchoveta stocks have fluctuated due to El Niño conditions and overharvesting, but most recent statistics indicate that they provide a third to half of the world supply of both fishmeal and oil
[81]. Peruvian anchoveta are almost exclusively harvested for export as a feed ingredient (as fishmeal and oil). Only $2 \%$ of Peruvian anchoveta are used for human consumption [79] despite food insecurity and micronutrient deficiencies in Peru and surrounding countries $[11,79]$.

In 2006, the Oceana Center for Environmental Sustainability (CES) at the Cayetano Heredia University in Lima set out to reshape the way anchoveta were used in Peru by promoting them as human food via the campaign "Semana de la Anchoveta" (Anchovy Week) (personal communication, Patricia Majluf, Oceana). Working with Peru's top celebrity chef on a nationally recognized TV cooking show, CES was able to broadcast their message about the sustainability, health benefits, and flavor of Peru's national fish, the anchoveta. The story caught the attention of the president of Peru, and after a meal with him at the Presidential Palace, the campaign had the backing of the government. A subsequent law allocated $8 \%$ of Peru's government spending on food toward anchoveta. Anchovy Week was repeated in 2007, 2009, and 2012, though the founder of the campaign admits it never reached her expectations in terms of public participation (personal communication, Patricia Majluf, Oceana). A lesson we can draw from Anchovy Week is that enacting food system changes requires adjustments not only in policy, but also throughout the supply chain, and among consumers. For example, the anchoveta fishing quota is solely based on reduction fishmeal uses, not producing food on food-grade anchovy. If vessels in the industrial fleet could use their catch for human consumption, the ensuing supply could be at a scale that would make production for human consumption economically viable. Fresh and frozen product forms, and new more convenient presentation formats (i.e., dried, minced) are needed to attract more consumers beyond those currently eating canned anchovies. These issues may include environmental, social, and economic trade-offs [81] and require unraveling and replacing current incentives in the fisheries policy that maintain the status quo [82].

\section{State-level policy: Farm to School programs}

In the section on health policies, we describe several nutrition assistance programs that include seafood. One innovative method for introducing seafood into 
nutrition assistance programs is through the National School Lunch Program (NSLP) using a concept called "Fish to School" (related to "Farm to School" programs). The State of Alaska has been proactive in navigating the bureaucratic requirements that must be fulfilled in order to source, purchase, and serve local fish like pollock, salmon, cod, halibut, and rockfish in school cafeterias [83]. Like other states, the Alaska state government requests that USDA purchases bulk quantities of commodity seafood (mainly canned pink salmon and catfish) for entitlement programs and through schools with CNPs. Alaska also provides grants to reimburse schools that purchase Alaskan-caught seafood through the Nutritional Alaskan Foods in Schools (NAFS) program. The NAFS helps schools better align meals with the national dietary guidelines and has its underpinnings in a 2010 state law to promote local agriculture in public schools [84]. The Alaska Fish to School effort aims to improve student health via seafood consumption, help students understand where their food comes from, provide traditional foods for schools, and acknowledge the cultural and economic significance of purchasing local seafood [83]. A study of the Alaska Fish to School program found that school fish meals were well aligned with the local foodways of the community, and purchasing local seafood engendered goodwill with parents and the community [84]. Challenges for schools implementing Fish to School in Alaska were finding seafood suppliers, ordering appropriate quantities of fish, and finding suitable recipes [84]. Implementation of the program also requires that there is demand for new foods, that they are available domestically from a pool of vendors, and that there is capacity within industry to provide necessary quantities. Oregon, Massachusetts, and New Hampshire are also working on similar Fish to School programs [85-87], which highlights an opportunity for repeating these innovative programs in other coastal states.

\section{Food procurement: connections among universities, hospitals, and regional fisheries}

Universities, hospitals, and other groups with institutional food procurement can play a key role in connecting local fisheries to improved diets [88]. Universities and hospitals are increasingly interested in the sustainability of their physical campuses as well as of the services they offer. Sustainability has become a "core value" of these institutions that requires mainstreaming throughout their operations. As part of this process, most universities have developed sustainability plans that cover a range of issues from procurement and building practices to improving energy and water use efficiency and reducing their overall carbon footprint. Food service procurement is often seen as a component of these plans. Some universities are rethinking their relationships with local economies as well as their ability to provide fresh local health food options for students. While the focus of these efforts has been on the local and regional procurement of agricultural products, some institutions are connecting with local fisheries.

In Boston, Massachusetts, improved technology around fish marketing is enabling regional universities (such as Boston University, Harvard University, and the University of Connecticut) to buy thousands of pounds of locally caught fish at competitive prices. Red's Best, an innovative seafood dealer, provides fish caught on day boats from Rhode Island to Maine directly to universities through negotiated partnerships [89]. By using QR codes that track where, when, and who caught the fish, universities are able to confirm the chain of custody and ensure that they are purchasing seafood caught locally or regionally. While universities continue to purchase much of their seafood from national distributors, purchases from Red's Best are growing as a share of total university seafood purchases in participating institutions.

Hospitals are also reflecting on the social and environmental impacts of their purchases. The quality as well as the source of hospital food can influence regional agricultural systems and markets for regionally caught seafood, not to mention health outcomes for patients. Like universities, hospitals are also developing sustainability plans, which often include increasing the amount of locally sourced food as a component of sustainability. Healthcare Without Harm is an international coalition of hospitals, community groups, environmental health organizations, and others that are working together to improve the overall contribution to health that a hospital can make beyond the medical services offered to patients [90]. The food procurement components of these plans have most often focused on agricultural products, leaving seafood sourcing to traditional mechanisms. However, through partnerships with local NGOs, some hospitals in New England are engaging with their suppliers on where their seafood comes from, as well as purchasing seafood directly through local community-supported fisheries (CSFs) [91], which are currently being encouraged in the Northeast USA through support from the Northwest Atlantic Marine Alliance (NAMA). These partnerships are helping to achieve "optimum yield" in fisheries by encouraging the purchase of US caught seafood in regional institutions.

\section{Private sector: business opportunity}

Bill Carvalho is the founder of Wild Planet, a canned seafood company. In 2001, a tour of the Monterey Bay Aquarium led to a realization of the economic opportunities available in exclusively selling sustainably harvested 
seafood, including forage fish, that are low in mercury and high in omega-3 PUFAs (personal communication, Bill Carvalho). In 2004, Wild Planet began selling canned tuna that met these standards, and later added canned sardines, anchovies, and mackerel. In 2008, Wild Planet received backing from a private equity firm involved with the Packard Foundation, enabling it to grow into one of the only American companies selling domestic forage fish, among other products, to the domestic mass market. Wild Planet products are now featured in many major grocery store chains in the US alongside traditional canned seafood.

The company's emphasis on sustainability has meant that product sourcing and supply chain management require constant attention. Tuna is purchased directly from US tuna fishermen or from the Japanese pole and troll fleet. Mackerel is also purchased from Japan. Originally, sardines were purchased from West Coast bait vendors; however, unreliable sizes of fish and a recent moratorium on sardine harvests meant the company had to source sardines primarily from Japan, and the USA as available. Most of Wild Planet's fish are canned in Vietnam, in part because the labor prices are more competitive, but also because Carvalho has had difficulty trying to revive the US West Coast seafood canning industry. Wild Planet also sources and cans anchovies in Peru, in an effort to support the Peruvian food fish canning industry. The story of Wild Planet highlights the international nature of the seafood supply, and the challenges for one company that attempts to source and process environmentally sustainable domestic seafood that is of high nutritional value.

\section{Recommendations}

US national health policy can have a significant impact on seafood access, utilization, and consumer seafood purchasing and consumption patterns. However, many of these policies, regulations, and guidance documents have been developed without any cross-integration to fisheries policies and regulation. As a result, government efforts to improve population health miss many opportunities for sourcing domestic, sustainably caught or farmed seafood. Others have raised similar concerns about misalignment of nutrition policy and agriculture policy [92].

Fisheries policy is also detached from, but integral to, public health. Fisheries and aquaculture policies refer frequently to the importance of fish as food for Americans; however, the emphasis of fisheries regulations and the science produced to support it have been on sustaining the resource and reducing impacts on fishing businesses without considering the broader outcomes, such as the production of food for the nation, that are defined in the MSA as necessary to achieve not just maximum sustainable yield but the overarching goal of optimum yield, or OY [MSA Sect. (3)(33)]. ${ }^{3}$ There is also a general disconnect between fisheries and consumers, such that the average citizen is often unaware of where their seafood comes from [93].

Aligning fisheries and health policies is imperative to achieving food security. Change will need to occur at multiple levels of policy and across various domains and dimensions of the food system (e.g., social, political, biophysical, economic) [94]. Institutions including seafoodrelated businesses, hospitals, state government agencies, NGOs, and academia can also play a role in better weaving together fisheries and health priorities (as we describe in "Synergy between fisheries and health policy" section). Drawing from these examples and our own professional experiences, we have developed a set of recommendations for integrating fisheries, aquaculture, and health policies.

The following bullets describe a number of ways to connect US health policy to fisheries and aquaculture policy, within the context of food production.

- Strengthen federal agency linkages Government agencies often work on similar topics but approach them from different disciplines or have divergent outcome measures. We see the following opportunities for stronger agency linkages: (1) integrate seafood consumption and nutrition guidance from other federal agencies with NOAA Fish Watch, a national database for sustainable seafood [95]; (2) include sustainable sourcing in the US Dietary Guidelines, with input from NMFS and others on seafood sustainability; (3) coordinate activities between FDA's seafood import inspection program and NOAA's seafood traceability initiative; (4) integrate state advisories for recreational fishing with state guidelines for self-caught fish consumption with support from EPA, FDA, NMFS, and FWS [52]; (5) connect seafood to the Obama White House backed initiative "Local Foods, Local Places" that connects multiple agencies around agricultural products [96]; and (6) move toward a national food policy that recognizes how fisheries and agriculture policy can support human health and the environment [97].

- Use federal agency purchasing power The federal government has substantial purchasing power, which could be leveraged to purchase sustainable seafood through: (1) increasing the diversity of bulk domestic

\footnotetext{
${ }^{3}$ Some economists have also argued for the inclusion of maximum economic yield (MEY) in definitions of OY. However, given that MEY leads to lower fishery yields than MSY, this risks contradicting the requirement to consider food production (see [108]).
} 
seafood products included in USDA Nutrition Assistance Programs; (2) supporting states in developing "Fish to School" programs to purchase domestic sustainably harvested and farmed seafood with National School Lunch Program funds; and (3) changing institutional food procurement polices [88] (e.g., the Federal Food Service Purchasing Guidelines) for food sold at federal buildings and in the military so they support sustainably harvested and farmed seafood.

- Foster federal agency investments in people Investments are commonly made by NMFS on the harvesting side of fisheries-vessel buybacks, and payments for involvement in cooperative research. But sustainable fisheries and sustainable seafood require new skills and relationships for fishermen and others involved in the supply chain in order to build new connections that will enable selling locally, regionally, to institutions, or using other supply chains that serve as an alternative to the current high import/ export model. Innovations in fisheries, such as traceability technology, community-supported fisheries, and direct marketing, could be expanded rapidly with targeted government funds.

- Shift assumptions about fisheries management (1) Expand the scope of fisheries management's general consideration of fish as being a food to more specifically include food systems and supply chains that form part of the broader socio-ecological connections integral to the viability and resilience of fishing businesses [98] and to think of fishing communities as part of this system rather than simply the home of fishermen or a landing site for vessels. This is a radical shift from the knowledge and training that most individuals who work in fisheries possess, and would require new collaborations. (2) Recognize that markets are not always the most effective way to distribute seafood to achieve MSA objectives beyond revenue and profit. In some fisheries, markets may serve objectives of food production and regional distribution better than others. Fisheries assessments will need to recognize that achieving optimum yield requires consideration of factors beyond fish stock sustainability and social and economic impacts to the harvest sector and fishing communities. Given that food is one of the elements of optimum yield, NMFS must consider the broader food system and seek partners who can operate in realms beyond its limited regulatory purview.

- Change how success is measured How we measure success in fisheries management matters. Focusing on ecological sustainability (the Fisheries Stock Sustainability Index or FSSI, for example) is an incomplete picture of whether the greatest benefits to the nation are being achieved. A stock might be in good health but might be under performing in terms of its contribution to the food system. Fishery performance measures could overlap with other government agency performance measures to reinforce and clarify connections between food policy and fisheries policy, expanding beyond the harvest sector to include seafood distribution, food access, supply chain, and consumption patterns.

- Foster new social science research Fisheries social science research has focused primarily on the harvesting sector and fishing communities. New areas of research that combine traditional social science fisheries research with food systems, health policy, and social justice research are necessary. Additional studies are needed on, for example: consumer preferences and consumption patterns with respect to lesserknown seafood products harvested from domestic sustainable fisheries and domestic aquaculture operations; interventions for reducing consumer seafood waste, such as clear package labeling or education [99]; and policy studies of how the Affordable Care Act can be leveraged to purchase local seafood for private hospitals and healthcare facilities [100]. We need to better integrate data on seafood access, consumption, and local markets with fisheries EAs and EISs. These research projects will necessarily involve collaborations across disciplines and research specialties.

- Create new relationships The perspectives used to inform the fisheries management process will need to be broadened to reflect the range of stakeholders associated with the larger fisheries system and food system. Currently, Fishery Management Council meetings are attended mainly by harvester organizations, environmental NGOs and, to differing degrees by region, processing representatives. Consumer groups, public health professionals, civil society organizations, and local seafood marketers are largely absent from the collaborative management process, in part at least because they are not targeted for announcements of these meetings and may therefore be unaware of them. Increased outreach by Regional Fishery Management Councils might help to alleviate this. One promising evolution in the Northeast Region is the creation of a Seafood Marketing Group within the NMFS Greater Atlantic Regional Fisheries Office [101] that brings together processors, harvesters, chefs, scientists, educators, state food system representatives, and others to consider how to add value to the fish harvested in the region. Another new relationship worth exploring and supporting in a broader context is a joint policy statement from 
health professional associations (American Public Health Associations, American Medical Association, and American Society of Nutrition) and fisheries and aquaculture associations (American Fisheries Society, US Aquaculture Association) about the importance of synergy between the fisheries and health fields.

\section{Conclusions}

Managing fisheries to promote optimal nutrition and efficient food production likely requires a different approach to fisheries management-new outcomes will need to be monitored, new approaches found and fisheries, aquaculture, and health policies better integrated. The Magnuson-Stevens Act as well as NMFS strategic guiding documents all highlight the importance of fish as food, as do the USDA/HHS nutritional guidelines. However, the implementation of the MSA has not focused on food production outcomes. What happens to fish beyond the harvesting and processing level is currently beyond the scope of factors considered by the councils. Council decisions are informed by impact assessments that focus on harvesters, fishing businesses, and to some degree on impacts to fishing communities.

Simultaneously, while health policies such as the US Dietary Guidelines indicate the need to consume more fish, little consideration is given to the sustainability or source of fish, their connections with US fisheries systems, and global distribution of seafood. Nonetheless, some states have implemented "Fish to School" programs in school districts, and more opportunities for bulk purchasing of sustainably caught or raised seafood exist in nutrition assistance programs and institutional food-buying programs. Seafood businesses, universities, hospitals, NGOs, and other actors are also beginning to make connections between public health, fisheries, and aquaculture. These efforts are a positive sign because change will need to occur at multiple levels and across various domains (federal, state, and local) and dimensions of the food system (e.g., social, political, biophysical, and economic). Aligning fisheries, aquaculture, and health policies should begin first where the most promising opportunities exist. There are numerous small steps to begin this process with shared responsibility among government, industry, and civil society. We also call on researchers to continue addressing questions and issues raised here, and develop and test theories of change that move us in a direction toward a more just, equitable, and sustainable food system.

\section{Abbreviations}

APHIS: Animal and Plant Health Inspection Service; CDC: Centers for Disease Control; CNP: Child Nutrition Program; DOC: Department of Commerce; HHS: Department of Health and Human Services; EPA: Environmental Protection
Agency; EEZ: Exclusive Economic Zone; FWS: Fish and Wild life Service; FDA: Food and Drug Administration; HACCP: hazard analysis and critical control point; IUU: illegal, unregulated, unreported; MSA: Magnuson-Stevens Fishery Conservation and Management Act; MeHg: methylmercury; MMT: million metric tons; NMFS: National Marine Fisheries Service; NOAA: National Oceanic and Atmospheric Administration; NSLP: National School Lunch Program; NAMA: Northwest Atlantic Marine Alliance; WIC: Nutrition Program for Women, Infants, and Children; PUFAs: omega-3 polyunsaturated fatty acids; POPs: persistent organic pollutants; SNAP: Supplemental Nutrition Assistance Program; USDA: Department of Agriculture; US: United States.

\section{Authors' contributions}

All authors contributed to early brainstorming, developing the study questions, designing the study, and outlining the manuscript; DCL and PPdS wrote a large portion of the manuscript with help from PMC and JO; DCL and JPF developed tables and figures; and all authors reviewed and edited the final manuscript. All authors read and approved the final manuscript.

\section{Author details}

1 Johns Hopkins Center for a Livable Future, Johns Hopkins University, 615 N. Wolfe Street, Baltimore, MD, USA. ${ }^{2}$ Department of Environmental Health and Engineering, Bloomberg School of Public Health, Johns Hopkins University, 615 N. Wolfe Street, Baltimore, MD, USA. ${ }^{3}$ Social Sciences Branch, Northeast Fisheries Science Center, National Marine Fisheries Service, 166 Water Street, Woods Hole, MA, USA. ${ }^{4}$ Department of Health, Behavior, and Society, Bloomberg School of Public Health, Johns Hopkins University, 624 N. Broadway, Baltimore, MD, USA.

\section{Acknowledgements}

The authors would like to thank the following individuals for their helpful discussion: Dr. Patricia Majluf, Vice President of Oceana Peru; Paul Johnson, owner of Monterey Fish Market; Bill Carvalho, owner of Wild Planet; and Janice Fitzgeral, Household Programs Operations Branch Chief at the US Department of Agriculture, Food, and Nutrition Service. The authors also thank Eric Thunberg and Michael Simpson of NOAA Fisheries, Shawn McKenzie and Robert Martin at the Johns Hopkins Center for a Livable Future, and Anthony So at the Johns Hopkins Bloomberg School of Public Health for reviewing a draft of the manuscript.

\section{Competing interests}

The authors declare that they have no competing interests.

\section{Availability of supporting data}

All data in the tables and manuscript text have references for primary data sources.

\section{Consent for publication}

All the authors consent to submitting the manuscript for publication.

\section{Declarations}

The authors received permission from participants in the case studies to publish their data.

\section{Funding}

Support for DCL and JPF was provided by the Johns Hopkins Center for a Livable Future with a gift from the GRACE Communications Foundation. PMC, JO, and PPdS were supported by NOAA Fisheries, or NMFS. The funders had no role in study design, data collection and analysis, decision to publish, or preparation of the manuscript.

Received: 13 August 2016 Accepted: 18 January 2017

Published online: 01 June 2017
References

1. Food and Agriculture Organization of the United Nations. The state of world fisheries and aquaculture 2014. 2014: Rome

2. Weichselbaum E, et al. Fish in the diet: a review. Nutr Bull. 2013;38(2):128-77. 
3. Mahaffey $\mathrm{KR}$, et al. Balancing the benefits of $\mathrm{n}-3$ polyunsaturated fatty acids and the risks of methylmercury exposure from fish consumption. Nutr Rev. 2011;69(9):493-508.

4. Sanders TA. Protective effects of dietary PUFA against chronic disease: evidence from epidemiological studies and intervention trials. Proc Nutr Soc. 2014;73(01):73-9.

5. U.S. Department of Health and Human Services and U.S. Department of Agriculture. 2015-2020 Dietary guidelines for Americans. 2015.

6. U.S. Department of Health and Human Services and U.S. Department of Agriculture. Dietary guidelines for Americans, 2010. 2010.

7. Hilborn R, et al. State of the world's fisheries. Annu Rev Environ Resour. 2003;28(1):359.

8. Jenkins $D J$, et al. Are dietary recommendations for the use of fish oils sustainable? Can Med Assoc J. 2009;180(6):633-7.

9. Brunner EJ, et al. Fish, human health and marine ecosystem health: policies in collision. Int J Epidemiol. 2009;38(1):93-100.

10. Greene J, et al. Fish oils, coronary heart disease, and the environment. Am J Public Health. 2013;103(9):1568-76.

11. Golden C, et al. Nutrition: fall in fish catch threatens human health. Nature. 2016;534(7607):317.

12. Pauly $\mathrm{D}$, Zeller $\mathrm{D}$. Catch reconstructions reveal that global marine fisheries catches are higher than reported and declining. Nat Commun. 2016;7:10244. doi:10.1038/ncomms10244.

13. Worm B, et al. Rebuilding global fisheries. Science. 2009;325(5940):578-85.

14. Worm B, et al. Impacts of biodiversity loss on ocean ecosystem services. Science. 2006;314(5800):787-90.

15. Rockström J, et al. A safe operating space for humanity. Nature. 2009:461(7263):472-5.

16. Pauly $D$, et al. Fishing down marine food webs. Science. 1998;279(5352):860-3.

17. Costello $\mathrm{C}$ et al. Global fishery prospects under contrasting management regimes. In: Proceedings of the national academy of sciences, 2016. p. 201520420.

18. Waters $\mathrm{CN}$, et al. The Anthropocene is functionally and stratigraphically distinct from the Holocene. Science. 2016;351(6269):aad2622.

19. Tidwell JH, Allan GL. Fish as food: aquaculture's contribution. EMBO Rep. 2001;2(11):958-63.

20. FAO. State of the world fisheries and aquaculture in 2014. Rome: United Nations FAO Fisheries and Aquaculture Department; 2014.

21. Naylor R, Burke M. Aquaculture and ocean resources: raising tigers of the sea. 2005:30:185-218.

22. Metian AGTM. Fishing for feed or fishing for food: increasing global competition for small pelagic forage fish. AMBIO J Hum Environ. 2009;38(6):294-302.

23. Fry JP, et al. Environmental health impacts of feeding crops to farmed fish. Environ Int. 2016;91:201-14.

24. Troell $\mathrm{M}$, et al. Does aquaculture add resilience to the global food system? Proc Natl Acad Sci. 2014;111(37):13257-63.

25. Olson J, Clay PM, Pinto da Silva P. Putting the seafood in sustainable food systems. Mar Policy. 2014;43:104-11.

26. He K, et al. Accumulated evidence on fish consumption and coronary heart disease mortality a meta-analysis of cohort studies. Circulation. 2004;109(22):2705-11.

27. Loring PA, Gerlach SC. Searching for progress on food security in the North American North: a research synthesis and meta-analysis of the peer-reviewed literature. Arctic. 2015:68(3):380-92.

28. Kittinger JN, et al. From reef to table: social and ecological factors affecting coral reef fisheries, artisanal seafood supply chains, and seafood security. PLoS ONE. 2015;10(8):e0123856.

29. Islam D, Berkes F. Indigenous peoples' fisheries and food security: a case from northern Canada. Food Secur. 2016;8(4):815-26.

30. Tilden J, et al. Health advisories for consumers of Great Lakes sport fish: is the message being received? Environ Health Perspect. 1997;105(12):1360.

31. Steinback S, Wallmo K, Clay P. Saltwater sport fishing for food or income in the Northeastern US: statistical estimates and policy implications. Mar Policy. 2009;33(1):49-57.

32. Gould LH, et al. Surveillance for foodborne disease outbreaks—United States, 1998-2008. MMWR Surveill Summ. 2013;62(2):1-34.
33. Lipp E, Rose J. The role of seafood in foodborne diseases in the United States of America. Revue Scientifique et Technique-Office International des Epizooties. 1997;16(2):620-40.

34. Nesheim MC, Yaktine AL. Seafood choices: balancing benefits and risks, ed. I.o. Medicine. 2007: National Academies Press, Washington, DC.

35. NOAA Fisheries. 2016 April 12, 2016. http://www.nmfs.noaa.gov/.

36. NOAA Office of Aquaculture. 2016. http://www.nmfs.noaa.gov/ aquaculture/.

37. USDA. Aquaculture. 2016 April 12. 2016. http://www.usda.gov/wps/ portal/usda/usdahome?navid=AQUACULTURE.

38. FDA. Animal and veterinary. 2016. http://www.fda.gov/ AnimalVeterinary/.

39. USDA-APHIS. Focus on fish health. 2016 April 12, 2016. https://www. aphis.usda.gov/focusonfish/aphis-aquaculture-program.php.

40. USDA. Organic aquaculture. 2016 April 12, 2016. https://afsic. nal.usda.gov/aquaculture-and-soilless-farming/aquaculture/ organic-aquaculture.

41. Love DC, et al. Veterinary drug residues in seafood inspected by the European Union, United States, Canada, and Japan from 2000 to 2009. Environ Sci Technol. 2011;45(17):7232-40.

42. NOAA, Magnuson-Stevens Fishery Conservation and Management Act Seafood Import Monitoring Program. 2016. pp. 88975-88998.

43. USDA. Meat, poultry, fish, and shellfish CIDs. n.d. April 12, 2016. https:// www.ams.usda.gov/grades-standards/cid/meat.

44. FDA. The imported seafood safety program. 2016 April 12, 2016. http:// www.fda.gov/Food/GuidanceRegulation/ImportsExports/Importing/ ucm248706.htm.

45. FDA. Guidance for industry: HACCP regulation for fish and fishery products; questions and answers for quidance to facilitate the implementation of a HACCP system in seafood processing. 2016 April 12, 2016. http://www.fda.gov/Food/GuidanceRegulation/GuidanceDocumentsRegulatorylnformation/Seafood/ucm176892.htm.

46. National Shellfish Sanitation Program. Guide for the control of molluscan shellfish 2013 revision. 2013.

47. FoodSafety.gov. Selected federal agencies with a role in food safety. n.d. April 12, 2016. http://www.foodsafety.gov/about/federal/index.html.

48. Millen B, Lichtenstein AH, Abrams S, Adams-Cambell L, Anderson C, Brenna JT, Campbell W, Clinton S, Foster G, Hu F, Nelson M, Neuhouser M, Perez-Escamilla R, Siega-Riz AM, Story M. Scientific report of the 2015 dietary guidelines advisory committee. 2015.

49. Wood-Wright N. New U.S. dietary guidelines ignore broad support for food sustainability. 2016, Johns Hopkins HUB.

50. Lagasse LP, Love DC, Smith KC. Country-of-origin labeling prior to and at the point of purchase: an exploration of the information environment in Baltimore City grocery stores. Ecol Food Nutr. 2014;53(1):58-80.

51. EPA. National listing of fish advisories. 2016 April 12, 2016. http://fishadvisoryonline.epa.gov/General.aspx.

52. Love DC, Hawes M, Harding J. State-level recreational fishing regulations and fish consumption advisories in the United States: identifying opportunities for improved interagency collaboration. J Public Health Manag Pract. 2013;19(4):E11-9.

53. FDA. What you need to know about mercury in fish and shellfish. 2004 April 12, 2016. http://www.fda.gov/food/resourcesforyou/consumers/ ucm110591.htm.

54. Oken $\mathrm{E}$, et al. Decline in fish consumption among pregnant women after a national mercury advisory. Obstet Gynecol. 2003;102(2):346.

55. Birch RJ, et al. Trends in blood mercury concentrations and fish consumption among US women of reproductive age, NHANES, 1999-2010 Environ Res. 2014;133:431-8.

56. FDA. Fish: What pregnant women and parents should know. 2014.

57. USDA. Supplemental nutrition assistance program (SNAP). 2016 April 12, 2016. http://www.fns.usda.gov/pd/ supplemental-nutrition-assistance-program-snap.

58. USDA. Women, infants and children (WIC): links to state agency WIC approved food lists. 2016 April 12, 2016. http://www.fns.usda.gov/wic/ links-state-agency-wic-approved-food-lists.

59. USDA. The emergency food assistance program (TEFAP). 2016 April 12 , 2016. http://www.fns.usda.gov/tefap/about-tefap.

60. USDA. Food distribution program on Indian reservations (FDPIR). 2016 April 12, 2016. http://www.fns.usda.gov/fdpir/about-fdpir. 
61. USDA. National school lunch program factsheet. 2016. http://www.fns usda.gov/sites/default/files/NSLPFactSheet.pdf.

62. Jahns L, et al. Intake of seafood in the US varies by age, income, and education level but not by race-ethnicity. Nutrients. 2014;6(12):6060-75.

63. Oken $\mathrm{E}$, et al. Which fish should I eat? Perspectives influencing fish consumption choices. Environ Health Perspect. 2012;120(6):790.

64. Verbeke W, Vackier I. Individual determinants of fish consumption: application of the theory of planned behaviour. Appetite 2005;44(1):67-82.

65. NOAA. Fisheries of the United States 2013. Silver Spring: National Marine Fisheries Service Office of Science and Technology; 2014.

66. Moore LV, Thompson FE. Adults meeting fruit and vegetable intake recommendations_-United States, 2013. Morb Mortal Wkly Rep. 2015;64(26):709-13.

67. Abbott-Jamieson S, Clay PM. The long voyage to including sociocultural analysis in NOAA's national marine fisheries service. Mar Fish Rev. 2010;72(2):14-33.

68. Loring PA, Gerlach SC, Harrison H. Seafood as local food: food security and locally caught seafood on Alaska's Kenai Peninsula. J Agric Food Syst Commun Dev. 2013;3(3):13-30.

69. FWS. About the U.S. fish and wildlife service. 2016. http://www.fws.gov/ help/about_us.html.

70. NOAA. Aquaculture policy and regulation: NOAA's role. n.d. April 12 , 2016. http://www.nmfs.noaa.gov/aquaculture/policy/13_policy_and_ reg_homepage.html.

71. USDA. Aquaculture. n.d. April 12, 2016. http://www.usda.gov/wps/ portal/usda/usdahome?navid=AQUACULTURE.

72. USDA-ERS. Aquaculture Data. n.d. April 12, 2016. http://www.ers.usda. gov/data-products/aquaculture-data.aspx.

73. NOAA. Marine aquaculture strategic plan FY 2016-2020. 2015

74. Interagency Working Group on Aquaculture. National strategic plan for federal aquaculture research (2014-2019). 2014.

75. Kirkley JE et al. International trade in seafood and related products: An assessment of U.S. trade patterns. 2006, National Oceanographic and Atmospheric Administration, National Marine Fisheries Service. pp. $1-147$.

76. McClenachan L, et al. Do community supported fisheries (CSFs) improve sustainability? Fish Res. 2014;157:62-9.

77. National Marine Fisheries Service. Fisheries economics of the United States, 2012, E.a.S.A. Division, Editor. 2014.

78. Seelye KQ. In Maine, Last Sardine Cannery in the U.S. is Clattering Out. In: New York Times. 2010.

79. Pikitch $E$ et al. Little fish, big impact: managing a crucial link in ocean food webs., Lenfest Ocean Program, Editor. 2012: Washington, DC. p. 108.

80. Chavez FP, et al. The northern Humboldt Current System: brief history, present status and a view towards the future. Prog Oceanogr. 2008;79(2):95-105.

81. Avadí A, Fréon P, Tam J. Coupled ecosystem/supply chain modelling of fish products from sea to shelf: the Peruvian anchoveta case. PLOS ONE. 2014;9(7):e102057.

82. Christensen $\mathrm{V}$, et al. Valuing seafood: the Peruvian fisheries sector. Mar Policy. 2014;44:302-11.

83. Gagnon T. A guide to serving local fish in School Cafeterias, S.C. Society, Editor. n.d.

84. Izumi BT, et al. Serving fish in school meals: perceptions of school nutrition professionals in Alaska. J Child Nutr Manag. 2015;39(1):n1.

85. Profita C. Oregon delivers local seafood from boat to school. In: Oregon Public Broadcasting. 2013
86. Horwitz S. Sea to school: models of local, sustainable seafood for schools. 2015. http://www.farmtoschool.org/news-and-articles/ sea-to-school-models-of-local-sustainable-seafood-for-schools.

87. Zeiber R. Program seeks to bring local seafood back to the school lunch menu. In: New Hampshire Sea Grant. n.d.

88. Fitch C, Santo R. Instituting change: an overview of institutional food procurement and recommendations for improvement. The Johns Hopkins Center for a Livable Future, Editor. 2016.

89. nd. Red's Best. 2016 June 23, 2016. https://www.redsbest.com.

90. Goad M. Maine hospitals look to local fish and vegetables to improve health and patient satisfaction, in Portland Press Herald. ME: Portland; 2015.

91. Brinson $A$, Lee $M-Y$, Roundtree B. Direct marketing strategies: the rise of community supported fishery programs. Mar Policy. 2011;35(4):542-8.

92. Siegel KR et al. Association of higher consumption of foods derived from subsidized commodities with adverse cardiometabolic risk among us adults. JAMA Intern Med. 2016.

93. Da Silva PP, Fulcher C. Human dimensions of marine fisheries: using GIS to illustrate land-sea connections in the northeast US herring, Clupea harengus, fishery. Mar Fish Rev. 2005;67(4):19-25.

94. IOM (Institute of Medicine) and NRC (National Research Council). A framework for assessing effects of the food system, N.A. Press, Editor. 2015.

95. NOAA. Seafood watch. 2016 April 21. http://www.fishwatch.gov/.

96. na. Local Food, Local Places: Bringing Expertise and Creative Thinking to Community Economic Development. 2014 June 23, 2016. https://www. whitehouse.gov/blog/2014/12/03/local-food-local-places-bringingexpertise-and-creative-thinking-community-economic-

97. Bittman M et al. How a national food policy could save millions of American lives. In: Washington Post. 2015.

98. Stoll JS, et al. Expanding the 'geography' of resilience in fisheries by bringing focus to seafood distribution systems. Ocean Coast Manag. 2015;116:185-92.

99. Love DC, et al. Wasted seafood in the United States from production to consumption. Glob Environ Change. 2015;35:116-24.

100. Smith T, Palmer A, Martin R, Fitch C. Achieving the triple aim in health care reform: the importance of the food system. The Johns Hopkins Center for a Livable Future, Editor. 2016.

101. GARFO. Member links. 2016 May 17, 2016. http://www.greateratlantic fisheries.noaa.gov/educational_resources/seafood/links/index.html.

102. USDA-FNS. 2015 explanatory notes. 2015.

103. Papanikolaou Y, et al. US adults are not meeting recommended levels for fish and omega-3 fatty acid intake: results of an analysis using observational data from NHANES 2003-2008. Nutr J. 2014;13(1):1.

104. National Cancer Institute (NCI). Usual intake of total seafood 2007-2010. Epidemiology and Genomics Research Program. Online. https://epi. grants.cancer.gov/diet/usualintakes/pop/2007-10/table_a27.html.

105. Tran NL, et al. Estimated long-term fish and shellfish intake-national health and nutrition examination survey. J Eposure Sci Environ Epidemiol. 2013;23(2):128-36.

106. Wang $Y$, et al. Trends and correlates in meat consumption patterns in the US adult population. Public Health Nutr. 2010;13(09):1333-45.

107. NMFS. Commercial fisheries statistics. nd June 13, 2016. http:// www.st.nmfs.noaa.gov/commercial-fisheries/commercial-landings/ annual-landings/index.

108. Dueri S, Guillotreau P, Jiménez-Toribio R, Oliveros-Ramos R, Bopp $L$, Maury O. Food security or economic profitability? Projecting the effects of climate and socioeconomic changes on global skipjack tuna fisheries under three management strategies. Glob Environ Change. 2016:41:1-12. 